J. Dairy Sci. 95:5813-5820

http://dx.doi.org/10.3168/jds.2011-4182

(C) American Dairy Science Association ${ }^{\circledR}, 2012$.

\title{
Effects of methionine hydroxy copper supplementation on lactation performance, nutrient digestibility, and blood biochemical parameters in lactating cows
}

\author{
F. Wang, ${ }^{*}$ S. L. Li, ${ }^{* 1}$ J. Xin, ${ }^{\star}$ Y. J. Wang, ${ }^{*}$ Z. J. Cao, ${ }^{* 1}$ F. C. Guo, † and Y. M. Wangf \\ *State Key Laboratory of Animal Nutrition, College of Animal Science and Technology, China Agricultural University, Beijing, 100193, P. R. China \\ †Novus International Research Center, Beijing, 100085, P. R. China \\ ¥Novus International, 20 Research Park Drive, St. Charles, MO 63304
}

\begin{abstract}
The objective of this study was to investigate the effects of methionine hydroxy $\mathrm{Cu}\left[(\mathrm{HMTBA})_{2}-\mathrm{Cu}\right]$ supplementation on lactation performance, nutrient digestibility, and blood biochemical parameters in lactating cows. Thirty lactating Holstein cows were assigned to 1 of 3 treatments in a randomized block design: (1) $\mathrm{Cu}$ sulfate only (S): $12 \mathrm{mg}$ of $\mathrm{Cu}$ provided by $\mathrm{CuSO}_{4}$ per kilogram of concentrate; (2) $\mathrm{Cu}$ sulfate and (HMTBA) $2_{2^{-}}$ $\mathrm{Cu}(\mathrm{SM}): 6 \mathrm{mg}$ of $\mathrm{Cu}$ provided by $\mathrm{CuSO}_{4}$ and $6 \mathrm{mg}$ of $\mathrm{Cu}$ provided by (HMTBA) ${ }_{2}$-Cu per kilogram of concentrate; or (3) (HMTBA) ${ }_{2}$-Cu only (M): $12 \mathrm{mg}$ of Cu provided by $(\mathrm{HMTBA})_{2}-\mathrm{Cu}$ per kilogram of concentrate. The level of dietary $\mathrm{Cu}$ was determined according to the NRC (2001) requirement. This experiment lasted for $120 \mathrm{~d}$, with the first $20 \mathrm{~d}$ for adaptation and with sample and data collection beginning on $\mathrm{d} 21$. The milk yield and $4 \%$ fat-corrected milk yield of cows in the SM treatment tended to increase compared with those in the $\mathrm{S}$ and $\mathrm{M}$ treatments. Cows fed SM also tended to have higher NDF and ADF apparent digestibility values than did cows fed $\mathrm{S}$ or M. Plasma $\mathrm{Cu}$ concentration significantly increased for the SM treatment compared with the $\mathrm{S}$ and $\mathrm{M}$ treatments. Cows fed $\mathrm{S}$ had higher plasma $\mathrm{K}$ concentration than did cows in the other 2 treatments. In conclusion, replacing one-half of the dietary $\mathrm{Cu}$ sulfate with $(\mathrm{HMTBA})_{2}-\mathrm{Cu}$ increased plasma $\mathrm{Cu}$ concentration and tended to improve the neutral and acid detergent fiber apparent digestibility values and the lactation performance of lactating dairy cattle. Key words: dairy cow, lactation performance, methionine hydroxy copper, organic trace mineral
\end{abstract}

Received January 21, 2011.

Accepted June 15, 2012.

${ }^{1}$ Corresponding authors: lisheng0677@163.com and ruminant315 @126.com

\section{INTRODUCTION}

Previous studies have shown that $\mathrm{Cu}$ plays an important role in lactation performance (Engle and Spears, 2000; Loeffler et al., 2007), reproduction (Georgjevskii and Samokin, 1982), immune function (Stabel and Spears, 1993; Arthington et al., 1996), and rumen function (Ivan, 1988, 1989) in dairy cows. Copper deficiency always relates to a series of physiological and metabolic disorders (NRC, 2001). Copper deficiency in dairy cows is traditionally prevented by supplying a higher level of dietary inorganic $\mathrm{Cu}$ supplementation, in an attempt to guarantee digestion and absorption of the required amount from the gastrointestinal tract. A growing awareness of environmental problems caused by undigested $\mathrm{Cu}$ compounds has led to numerous research studies addressing the low absorption rate of inorganic $\mathrm{Cu}$ (Benke et al., 2008). Three major reasons for the low absorption rate of inorganic $\mathrm{Cu}$ are the animal species, diet composition, and source of $\mathrm{Cu}$. First, the fact that the $\mathrm{Cu}$ absorption in ruminant animals is far less than that in monogastric animals (Georgjevskii and Samokin, 1982; Suttle, 1991; NRC, 2001) is widely accepted. The extent of $\mathrm{Cu}$ absorption in dairy calves can be as high as $60 \%$ in their first 4 wk after birth; however, adult dairy cattle absorb only 1 to $5 \%$ of their $\mathrm{Cu}$ intake (Bremner et al., 1987). This is largely due to their rumen development and the rumen environment, where it may lead to the formation of a $\mathrm{Cu}$ complex with other elements in the absorption process (Dick, 1953; Gengelbach and Spears, 1998; Spears, 2003). Second, it is well documented that the $\mathrm{Cu}$ requirement varies greatly in ruminants, depending on concentrations of dietary S and Mo (Allen and Gawthorne, 1987; Gooneratne et al., 1989; Suttle, 1991). Third, several research studies have been carried out to address the absorption rate of different $\mathrm{Cu}$ sources, but the results have not been consistent for organic and inorganic forms of $\mathrm{Cu}$ (Nockels et al., 1993; Ward et al., 1993). In cattle fed diets that were high in $\mathrm{Mo}, \mathrm{Cu}$ proteinate was more 
bioavailable than $\mathrm{Cu}$ sulfate in some studies (Kincaid et al., 1986; Ward et al., 1996) but not in others (Wittenberg, et al., 1990). The relative bioavailability of $\mathrm{Cu}$ lysine was generally similar to that of cupric sulfate (Ward et al., 1993; Kegley and Spears, 1994).

Copper sulfate is a readily available and widely used inorganic $\mathrm{Cu}$ source (Chapman and Bell, 1963; McDowell, 1992), but the efficiency of absorption is very low for inorganic sources (NRC, 2001). The source of organic $\mathrm{Cu}$ used in the current study, methionine hydroxy $\mathrm{Cu}\left[(\mathbf{H M T B A})_{2}-\mathbf{C u}\right.$; Novus International Inc., St. Charles, MO], is a new chelating product composed of 2 molecules of 2-hydroxy-4-methythio butanoic acid (HMTBA) chelated with 1 molecule of $\mathrm{Cu}$. This experiment was conducted to determine whether replacing dietary $\mathrm{Cu}$ sulfate with $(\mathrm{HMTBA})_{2}-\mathrm{Cu}$ would improve the performance of dairy cows.

\section{MATERIALS AND METHODS}

The dairy cows selected were cared for in accordance with the practices outlined in the Guide for the Care and Use of Agricultural Animals in Research and Teaching (FASS, 2010).

\section{Treatments, Experimental Design, and Cow Management}

The study was conducted from July 20, 2008, to April 12, 2009, at the Hutubi Dairy Farm in Xinjiang (northwest China). Ten days before the start of the experiment, 30 Holstein dairy cows (DIM $=45 \pm 26$; milk yield $=31.8 \pm 2.4 \mathrm{~kg}$; parities $=1$ to 5 , and $\mathrm{BW}$ $=592 \pm 22 \mathrm{~kg}$ ) were assigned into 1 of 3 treatments using a randomized block design. Three treatments were (1) $\mathrm{Cu}$ sulfate only (S): $12 \mathrm{mg}$ of $\mathrm{Cu}$ provided by $\mathrm{CuSO}_{4}$ per kilogram of concentrate; (2) Cu sulfate and (HMTBA)2-Cu (SM): $6 \mathrm{mg}$ of $\mathrm{Cu}$ provided by $\mathrm{CuSO}_{4}$ and another $6 \mathrm{mg}$ of $\mathrm{Cu}$ provided by (HMTBA) ${ }_{2}-\mathrm{Cu}$ per kilogram of concentrate; or (3) (HMTBA) ${ }_{2}-\mathrm{Cu}$ only (M): $12 \mathrm{mg}$ of $\mathrm{Cu}$ provided by (HMTBA) ${ }_{2}$ - Cu per kilogram of concentrate. The supplementation level of $\mathrm{Cu}$ was determined according to the NRC (2001) requirement, and the $\mathrm{Cu}$ concentration in the basal diet was calculated separately $(9.78 \mathrm{mg} / \mathrm{kg})$. The trial was $120 \mathrm{~d}$ in duration, with the first $20 \mathrm{~d}$ for adaptation and with sample collection beginning on d 21 .

Cows in the experiment were component fed, and the $\mathrm{Cu}$ supplement was included in the compound premixes ( $1 \%$ of concentrate). Six feeders ( 5 cows/feeder) were responsible for daily feeding of the premix. The 5 cows the feeder was responsible for was randomly arranged daily. The compound premix was preweighed for each cow 3 times/d, and the keepers delivered it to the cows. The premix was added on top and stirred into the concentrate at every feeding. During the adaptation period, the experimental premixes S, SM, or M were gradually supplemented to their corresponding treatments and replaced the control premix by $10 \%$ more every day as a transition. The full replacement was achieved on $\mathrm{d}$ 10 and was maintained thereafter to the end of this experiment. Ingredients and nutrient composition of the experimental diets are listed in Table 1; the concentrate and forage were fed separately 3 times/d $(0400,1100$, and $1700 \mathrm{~h}$ ). In the current experiment, approximately $1.90 \mathrm{~kg}$ of corn silage, $0.54 \mathrm{~kg}$ of alfalfa hay, $0.40 \mathrm{~kg}$ of brewers grain, $3.65 \mathrm{~kg}$ of concentrate, and $1.80 \mathrm{~kg}$ of alfalfa hay were delivered to each cow in the morning feeding, and approximately $1.42 \mathrm{~kg}$ of corn silage, 0.18 $\mathrm{kg}$ of alfalfa hay, $0.30 \mathrm{~kg}$ of brewers grain, $2.74 \mathrm{~kg}$ of concentrate, and $1.50 \mathrm{~kg}$ of alfalfa hay were supplied to each cow in the noon and afternoon feedings. Water was available for ad libitum consumption. A mineral supplement block was not provided in the open lot. The (HMTBA $)_{2}$-Cu was supplied by the Novus International Trade Company (St. Charles, MO). Ingredients and nutrient levels of the diets are shown in Table 1.

\section{Data and Samples Collection}

Milk Yield and Milk Components. All cows on the farm were milked 3 times daily while feeding at 0430, 1130, and $1730 \mathrm{~h}$ using a pipeline milking machine. Milk yields of the experimental cows were recorded daily for the first $3 \mathrm{~d}$ of the experiment and then every $10 \mathrm{~d}$ for the remainder of the experiment. Milk samples were taken for the first $3 \mathrm{~d}$ of the experiment and then every $30 \mathrm{~d}$ at all milkings until the end of the experiment, and samples were analyzed for milk components at the DHI milk testing laboratory at Xinjiang Agricultural University (Urumqi, Xinjiang, China).

DMI and Digestibility. To calculate the DMI of individual cows, the amount of every ingredient offered was measured from d 1 to 3 , d 31 to 33 , d 61 to 63 , d 91 to 93 , and d 115 to 120 of the experiment, and the orts of individual cows during these days were collected and weighed after every feeding. Ingredient and orts samples were oven-dried at $65^{\circ} \mathrm{C}$ for $48 \mathrm{~h}$, ground to pass through a 1-mm screen using a Wiley mill (standard model 4, Arthur H. Thomas Co., Philadelphia, $\mathrm{PA}$ ), and stored at $-20^{\circ} \mathrm{C}$ for $\mathrm{DM}, \mathrm{OM}, \mathrm{NDF}$, and $\mathrm{ADF}$ analysis. During the period from d 115 to 120, 3 cows from each treatment with similar DMI were selected for a 5-d digestibility test, and the floor was cushioned with rubber mats during the test. Six fecal holders were arranged in shift, and were responsible for collecting 
Table 1. Ingredient composition and nutritional level of the experimental diets (\%, DM basis)

\begin{tabular}{|c|c|c|c|}
\hline \multirow[b]{2}{*}{ Item, ${ }^{1} \%$} & \multicolumn{3}{|c|}{ Treatment $^{2}$} \\
\hline & $\mathrm{S}$ & SM & M \\
\hline \multicolumn{4}{|l|}{ Ingredient } \\
\hline Corn silage & 24.60 & 24.60 & 24.60 \\
\hline Brewers grain & 4.90 & 4.90 & 4.90 \\
\hline Alfalfa hay & 17.70 & 17.70 & 17.70 \\
\hline Concentrate without premix ${ }^{3}$ & 52.80 & 52.80 & 52.80 \\
\hline Total & 100.00 & 100.00 & 100.00 \\
\hline \multicolumn{4}{|l|}{ Nutritional level } \\
\hline $\mathrm{CP}$ & 15.90 & 15.90 & 15.90 \\
\hline $\mathrm{NDF}$ & 40.20 & 40.20 & 40.20 \\
\hline $\mathrm{ADF}$ & 23.60 & 23.60 & 23.60 \\
\hline $\mathrm{OM}$ & 91.60 & 91.60 & 91.60 \\
\hline Ether extract & 6.40 & 6.40 & 6.40 \\
\hline $\mathrm{Ca}$ & 0.79 & 0.79 & 0.79 \\
\hline $\mathrm{P}$ & 0.44 & 0.44 & 0.44 \\
\hline $\mathrm{K}$ & 1.20 & 1.20 & 1.20 \\
\hline $\mathrm{Na}$ & 0.37 & 0.37 & 0.37 \\
\hline $\mathrm{Cl}$ & 0.41 & 0.41 & 0.41 \\
\hline Sulfur, ${ }^{4} \mathrm{mg} / \mathrm{kg}$ & $2,306.00$ & $2,309.00$ & $2,312.00$ \\
\hline $\mathrm{Cu}$ from $\mathrm{CuSO}_{4} \cdot 5 \mathrm{H}_{2} \mathrm{O}, \mathrm{mg} / \mathrm{kg}$ & 12.00 & 6.00 & - \\
\hline $\mathrm{Cu}$ from $(\mathrm{HMTBA})_{2}-\mathrm{Cu},{ }^{5} \mathrm{mg} / \mathrm{kg}$ & - & 6.00 & 12.00 \\
\hline Basal Cu level, ${ }^{6} \mathrm{mg} / \mathrm{kg}$ & 9.78 & 9.78 & 9.78 \\
\hline $\mathrm{Fe}, \mathrm{mg} / \mathrm{kg}$ & 214.44 & 214.44 & 214.44 \\
\hline $\mathrm{Zn}, \mathrm{mg} / \mathrm{kg}$ & 87.18 & 87.18 & 87.18 \\
\hline $\mathrm{Mn}, \mathrm{mg} / \mathrm{kg}$ & 46.11 & 46.11 & 46.11 \\
\hline Mo, mg/kg & 2.38 & 2.38 & 2.38 \\
\hline $\mathrm{NE}_{\mathrm{L}}{ }^{7} \mathrm{MJ} / \mathrm{kg}$ & 6.78 & 6.78 & 6.78 \\
\hline
\end{tabular}

${ }^{1}$ Defined based on the consecutive 3 -d intake of all cows determined in the adaptation period.

${ }^{2}$ Treatments: $\mathrm{S}=\mathrm{Cu}$ sulfate only: $12 \mathrm{mg}$ of $\mathrm{Cu}$ provided by $\mathrm{CuSO}_{4}$ per kilogram of concentrate; $\mathrm{SM}=\mathrm{Cu}$ sulfate and methionine hydroxy $\mathrm{Cu}\left[(\mathrm{HMTBA})_{2}-\mathrm{Cu}\right]: 6 \mathrm{mg}$ of $\mathrm{Cu}$ provided by $\mathrm{CuSO}_{4}$, and 6 $\mathrm{mg}$ of $\mathrm{Cu}$ provided by (HMTBA) ${ }_{2}$-Cu per kilogram of concentrate; $\mathrm{M}$ $=(\mathrm{HMTBA})_{2}-\mathrm{Cu}$ only: $12 \mathrm{mg}$ of $\mathrm{Cu}$ provided by $(\mathrm{HMTBA})_{2}-\mathrm{Cu}$ per kilogram of concentrate.

${ }^{3}$ Contained the following per kilogram of concentrate without premix: $48 \%$ corn grain, $16 \%$ wheat bran, $12 \%$ cottonseed meal, $6 \%$ cottonseed protein, $4 \%$ beet meal, $1 \%$ sunflower meal (extruded), $3.4 \%$ sunflower meal (solute), $3 \%$ grapeseed meal, $2 \%$ plastered starch urea, $1.5 \%$ limestone, $1.2 \%$ Ca phosphate, $1 \%$ premix, $0.1 \%$ detoxifier, $0.8 \%$ salt. ${ }^{4}$ Note that the difference for total $\mathrm{S}$ content brought about by replacing $\mathrm{CuSO}_{4}$ with (HMTBA) ${ }_{2}-\mathrm{Cu}$ was not all dissolvable. The change in methionine content was undetectable in this experiment.

${ }^{5}(\mathrm{HMTBA})_{2}-\mathrm{Cu}$ (Novus International Inc., St. Charles, MO) is composed of 2 molecules of 2-hydroxy-4-methythio butanoic acid (HMTBA) chelated with 1 molecule of $\mathrm{Cu}$.

${ }^{6}$ From corn silage, brewers dried grain, alfalfa hay, and concentrate.

${ }^{7} \mathrm{NRC}$ (2001) was used to calculate nutrient composition.

fecal samples of individual cows. Urine bags were adhered to the vulva of cows, and all urine was collected into plastic buckets. All feces were weighed and pooled for individual cows per day, and $2 \%$ intensively mixed feces were sampled and oven-dried at $65^{\circ} \mathrm{C}$ for $48 \mathrm{~h}$, ground to pass through a $1-\mathrm{mm}$ screen, and then stored at $-20^{\circ} \mathrm{C}$ in labeled valve bags for $\mathrm{DM}, \mathrm{OM}, \mathrm{NDF}$, and $\mathrm{ADF}$ analyses.
Blood Collection and Serum Preparation. Ten milliliters of jugular blood was taken from each cow before (at $0 \mathrm{~h}$ ) and at 1, 2, and $4 \mathrm{~h}$ after the morning feeding on d 4, 24, 64, 94, and 114 into blood collection tubes (Vacutainer; Becton Dickinson, Franklin Lakes, NJ). Before sampling, the skin was washed with Milli-Q water (Millipore Corp., Billerica, MA). The tubes with blood samples were centrifuged at 3,500 $\times g$ for $15 \mathrm{~min}$ to obtain serum, which was separated into several aliquots and stored at $-80^{\circ} \mathrm{C}$ in an ultra-low-temperature freezer (DW-86L286; Haier, Qingdao, China) until further analysis of serum biochemical parameters. Another set of 3-mL blood samples from each cow was anticoagulated with EDTA at the same time for the regular blood test.

\section{Analytical Procedures}

Nutritional Evaluation. Feed and feces samples were determined for DM at $65^{\circ} \mathrm{C}$ for $48 \mathrm{~h}$ in a forced-air oven (model 2000; Experimental Mill, Beijing, China) and were tested for OM (method 942.05; AOAC, 1990). Crude protein was determined using an automated $\mathrm{N}$ analyzer (Rapid NIII, Elementar, Hanau, Germany). Neutral detergent fiber was measured by the method of Van Soest et al. (1991) using heat-stable $\alpha$-amylase (No. A-3306; Sigma Chemical Co., St. Louis, MO) and $\mathrm{Na}$ sulfite, and ash concentration was corrected for the Ankom 200 fiber analyzer (Ankom Technology, Fairport, NY). The feed samples were also analyzed for ADF (method 973.18c; AOAC, 1990), ether extract (method 920.39; AOAC, 1990), Ca, and P by atomic absorption spectrometry (method 945.46; AOAC, 1990).

Milk Components. Milk components (protein, fat, lactose, and SNF) in the fresh milk of all cows were determined with a near-infrared milk ingredient analyzer (Miris Dairy Milk Analyser; Miris AB, Uppsala, Sweden) in the DHI laboratory at Xinjiang Agricultural University. Milk was deproteinized (Ekinci and Broderick, 1997) and analyzed for MUN by colorimetric assay and methods as described by Huang et al. (2009).

Blood Biomarkers. Blood metabolites and parameters, such as total protein, albumin, serum urea $\mathrm{N}$, total cholesterol, high-density lipoprotein cholesterol, low-density lipoprotein cholesterol, triglycerides, and K of serum were analyzed using a clinical autoanalyzer (c8000; Abbott Laboratories, Abbott Park, IL). The contents or activities of ceruloplasmin, malondialdehyde, total superoxide dismutase, $\mathrm{Cu}$-Zn-superoxide dismutase, Mn-superoxide dismutase, and glutathione peroxidase in serum were detected using standard pro- 
Table 2. Effects of methionine hydroxy $\mathrm{Cu}\left[(\mathrm{HMTBA})_{2}-\mathrm{Cu}\right]$ on the milk composition of cows

\begin{tabular}{|c|c|c|c|c|c|}
\hline \multirow[b]{2}{*}{ Item } & \multicolumn{3}{|c|}{ Treatment $^{1}$} & \multirow[b]{2}{*}{ SEM } & \multirow[b]{2}{*}{$P$-value } \\
\hline & $\mathrm{S}$ & SM & M & & \\
\hline DMI, kg/d & 19.2 & 20.3 & 19.8 & 0.35 & 0.23 \\
\hline Milk vield, $\mathrm{kg} / \mathrm{d}$ & 28.8 & 33.8 & 31.3 & 1.06 & 0.08 \\
\hline Fat, $\%$ & 3.81 & 3.74 & 3.75 & 0.06 & 0.81 \\
\hline Protein, $\%$ & 3.34 & 3.28 & 3.28 & 0.04 & 0.19 \\
\hline Lactose, $\%$ & 4.48 & 4.35 & 4.43 & 0.05 & 0.08 \\
\hline SNF, $\%$ & 8.63 & 8.84 & 8.63 & 0.05 & 0.33 \\
\hline Fat vield, $\mathrm{kg} / \mathrm{d}$ & 1.04 & 1.22 & 1.10 & 0.04 & 0.09 \\
\hline Protein yield, $\mathrm{kg} / \mathrm{d}$ & 0.92 & 0.92 & 0.90 & 0.03 & 0.72 \\
\hline Lactose yield, $\mathrm{kg} / \mathrm{d}$ & 1.23 & 1.23 & 1.21 & 0.04 & 0.45 \\
\hline Urea $\mathrm{N}, \mathrm{mg} / \mathrm{dL}$ & 18.39 & 17.70 & 18.83 & 0.45 & 0.19 \\
\hline $4 \% \mathrm{FCM}, \mathrm{kg} / \mathrm{d}$ & 26.1 & 30.1 & 27.5 & 0.91 & 0.06 \\
\hline
\end{tabular}

${ }^{1}$ Treatments: $\mathrm{S}=\mathrm{Cu}$ sulfate only: $12 \mathrm{mg}$ of $\mathrm{Cu}$ provided by $\mathrm{CuSO}_{4}$ per kilogram of concentrate; $\mathrm{SM}=\mathrm{Cu}$ sulfate and (HMTBA) ${ }_{2}-\mathrm{Cu}: 6 \mathrm{mg}$ of $\mathrm{Cu}$ provided by $\mathrm{CuSO}_{4}$, and another $6 \mathrm{mg}$ of $\mathrm{Cu}$ provided by $(\mathrm{HMTBA})_{2}-\mathrm{Cu}$ per kilogram of concentrate; $\mathrm{M}=(\mathrm{HMTBA})_{2}-\mathrm{Cu}$ only: $12 \mathrm{mg}$ of $\mathrm{Cu}$ provided by $(\mathrm{HMTBA})_{2}-\mathrm{Cu}$ per kilogram of concentrate.

cedures and commercial kits (Nanjing Jiancheng Biology Research Institute, Nanjing, China).

Serum Cu Concentrations. The concentrations of $\mathrm{Cu}$ in feed, fecal, and serum samples were determined using a SpectorAA-30 atomic absorption spectrophotometer (Varian Techtron Pty. Ltd., Mulgrave, Victoria, Australia) equipped with a programmable sample changer (Model PSC-56) and data acquisition system (Model DS-15). Measurements were performed at 324.7 $\mathrm{nm}$ for $\mathrm{Cu}$ by using hollow cathode lamps operated at 3 $\mathrm{mA}$ and bandwidths of $0.2 \mathrm{~nm}$. Acetylene was used as the assist gas, and the gas pressure and flow rate were $0.05 \mathrm{MPa}$ and 1,600 $\mathrm{mL} / \mathrm{min}$, respectively.

\section{Statistical Analysis}

Data were analyzed using repeated measures analysis models in the PROC MIXED procedure of SAS (SAS Institute, 2004). Cow was used as the experimental unit. The model used to analyze the data was

$$
\begin{aligned}
\mathrm{Y}_{\mathrm{ijk}}= & \mu+\operatorname{trt}_{\mathrm{i}}+\operatorname{cow}_{\mathrm{j}}\left(\operatorname{trt}_{\mathrm{i}}\right)+\operatorname{time}_{\mathrm{k}} \\
& +\operatorname{trt}_{\mathrm{i}} \times \operatorname{time}_{\mathrm{k}}+\mathrm{E}_{\mathrm{ijk}},
\end{aligned}
$$

where $Y_{i j k}$ is the dependent variable, $\mu$ is the overall mean, trt $_{\mathrm{i}}$ is the fixed effect of the ith treatment ( $\mathrm{i}=$ $1,2,3), \operatorname{cow}_{\mathrm{j}}\left(\operatorname{trt}_{\mathrm{i}}\right)$ is the random effect of the jth cow within the ith treatment $(\mathrm{j}=1, \ldots, 10)$, time $_{\mathrm{k}}$ is the fixed effect of sample collection/measurement time $(\mathrm{k}$ $=1, \ldots, 12$ for milk yield measurements, $\mathrm{k}=1, \ldots, 4$ for milk composition and blood analyses), $\operatorname{trt}_{\mathrm{i}} \times$ time $_{\mathrm{k}}$ is the fixed effect of the interaction between the ith treatment and the kth time, and $\mathrm{E}_{\mathrm{ijk}}$ is the random residual, $\sim \mathrm{N}\left(0, \delta_{\mathrm{e}}^{2}\right)$. Significant differences were declared at $P \leq 0.05$, and trends were reported at $0.05<P \leq$ 0.10 .

\section{RESULTS}

\section{Feed Intake and Lactation Performance}

No significant difference was observed in DMI among the treatments. The average milk yield $(P=0.08)$ and $4 \%$ FCM yield $(P=0.06)$ tended to increase for the SM treatment compared with the $\mathrm{S}$ and M treatments. Milk fat yield $(P=0.09)$ tended to be higher, whereas milk lactose content $(P=0.08)$ tended to be lower in the SM treatment than in the $\mathrm{S}$ and $\mathrm{M}$ treatments, as shown in Table 2.

\section{Nutrient Digestibility}

Methionine hydroxy $\mathrm{Cu}$ replacement had no influence on the digestibility of OM, CP, and ether extract $(P>0.1$; Table 3$)$. Replacing $50 \% \mathrm{Cu}$ sulfate with (HMTBA $)_{2}-\mathrm{Cu}$ (SM diet) tended to improve the apparent digestibility values of $\mathrm{NDF}(P=0.09)$ and ADF $(P=0.08)$, and the apparent digestibility values of $\mathrm{NDF}$ and ADF for cows in the SM treatment (57.1 and $55.1 \%)$ were higher than those for cows in the S (49.1 and $44.0 \%$ ) and $\mathrm{M}(49.0$ and $46.4 \%)$ treatments, as shown in Table 3.

\section{Blood Analysis}

A significant increase was observed for average serum $\mathrm{Cu}$ concentration in the SM treatment compared with the $\mathrm{S}$ treatment $(P<0.01)$, whereas a significant increase was observed for serum $\mathrm{K}$ concentration in the 
Table 3. Effects of methionine hydroxy $\mathrm{Cu}\left[(\mathrm{HMTBA})_{2}\right.$-Cu] on nutrient apparent digestibility

\begin{tabular}{|c|c|c|c|c|c|}
\hline \multirow[b]{2}{*}{ Item, \% } & \multicolumn{3}{|c|}{ Treatment $^{1}$} & \multirow[b]{2}{*}{ SEM } & \multirow[b]{2}{*}{$P$-value } \\
\hline & $\mathrm{S}$ & SM & M & & \\
\hline $\mathrm{OM}$ & 62.2 & 68.3 & 65.4 & 1.54 & 0.29 \\
\hline $\mathrm{CP}$ & 63.7 & 69.1 & 68.4 & 1.23 & 0.54 \\
\hline Ether extract & 50.4 & 59.1 & 51.9 & 1.83 & 0.21 \\
\hline $\mathrm{NDF}$ & 49.1 & 57.1 & 49.0 & 1.98 & 0.09 \\
\hline $\mathrm{ADF}$ & 44.0 & 55.1 & 46.4 & 1.54 & 0.08 \\
\hline
\end{tabular}

${ }^{1}$ Treatments: $\mathrm{S}=\mathrm{Cu}$ sulfate only: $12 \mathrm{mg}$ of $\mathrm{Cu}$ provided by $\mathrm{CuSO}_{4}$ per kilogram of concentrate; $\mathrm{SM}=\mathrm{Cu}$ sulfate and $(\mathrm{HMTBA})_{2}-\mathrm{Cu}: 6 \mathrm{mg}$ of $\mathrm{Cu}$ provided by $\mathrm{CuSO}_{4}$, and another $6 \mathrm{mg}$ of $\mathrm{Cu}$ provided by $(\mathrm{HMTBA})_{2}-\mathrm{Cu}$ per kilogram of concentrate; $\mathrm{M}=(\mathrm{HMTBA})_{2}-\mathrm{Cu}$ only: $12 \mathrm{mg}$ of $\mathrm{Cu}$ provided by (HMTBA $)_{2}$-Cu per kilogram of concentrate.

$\mathrm{S}$ treatment compared with the SM and M treatments $(0.01<P<0.05)$; the trends are shown in Figure 1. Other blood and serum parameters, such as the levels of serum total protein, total cholesterol, and total superoxide dismutase, are not presented in the tables because none of the parameters was significantly affected by treatment $(P>0.1)$.

a)

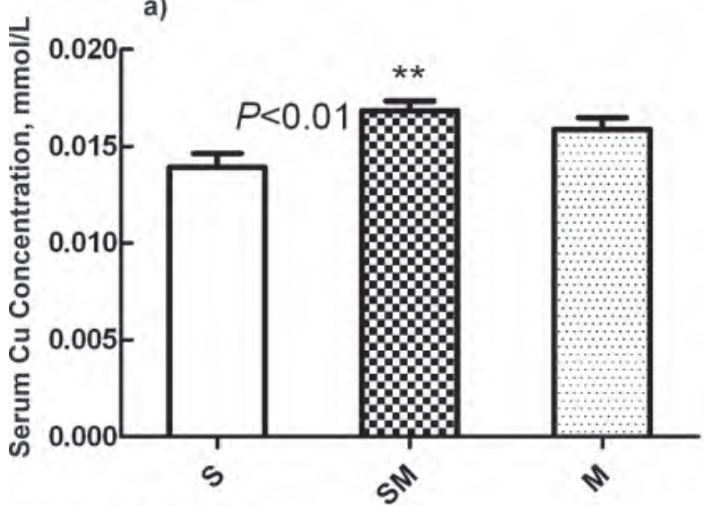

c)

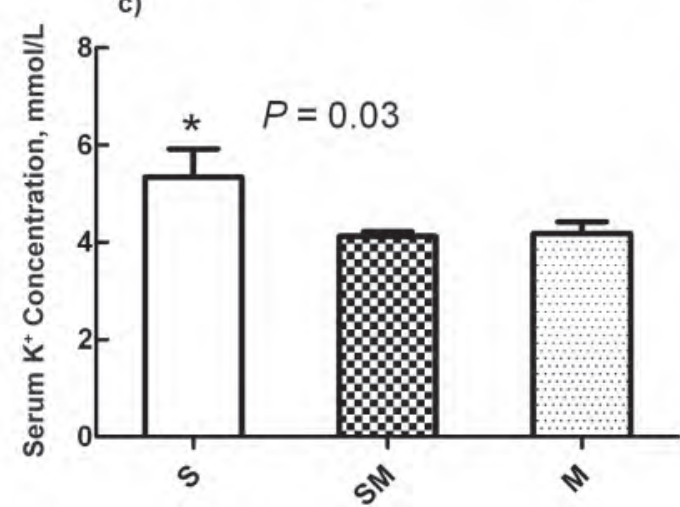

\section{DISCUSSION}

\section{Experimental Design}

Many previous studies on trace elements involved a combination of more than 2 elements (Nocek et al., 2006; Sharman et al., 2008; Siciliano-Jones et al., 2008) or several supplemental levels of different sources b)

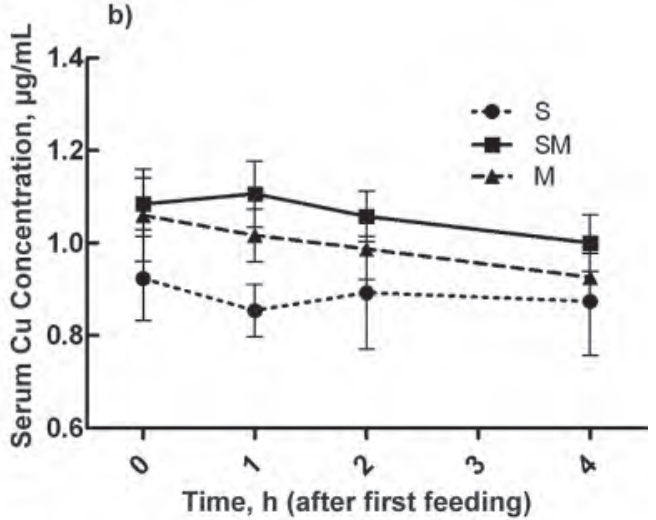

d)

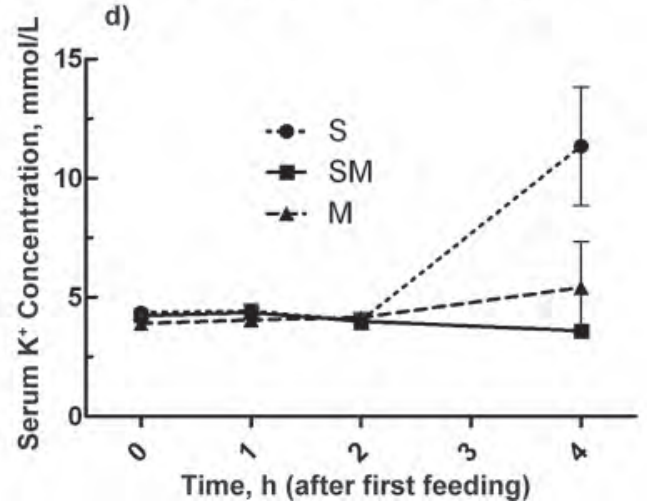

Figure 1. Concentrations and trends of serum $\mathrm{Cu}$ and $\mathrm{K}^{+}$. Treatments: $\mathrm{S}=\mathrm{Cu}$ sulfate only: $12 \mathrm{mg}$ of $\mathrm{Cu}$ provided by $\mathrm{CuSO}_{4}$ per kilogram of concentrate; $\mathrm{SM}=\mathrm{Cu}$ sulfate and methionine hydroxy $\mathrm{Cu}\left[(\mathrm{HMTBA})_{2}-\mathrm{Cu}\right]: 6 \mathrm{mg}$ of $\mathrm{Cu}$ provided by $\mathrm{CuSO}_{4}$, and another $6 \mathrm{mg}$ of $\mathrm{Cu}$ provided by $(\mathrm{HMTBA})_{2}$-Cu per kilogram of concentrate; $\mathrm{M}=(\mathrm{HMTBA})_{2}$-Cu only: $12 \mathrm{mg}$ of $\mathrm{Cu}$ provided by (HMTBA) ${ }_{2}$-Cu per kilogram of concentrate. ** indicates an increase $(P<0.01)$ in serum $\mathrm{Cu}$ concentration in the $\mathrm{SM}$ treatment compared with the $\mathrm{S}$ treatment; ${ }^{*}$ indicates an increase $(P$ $=0.03)$ in serum $\mathrm{K}$ concentration in the $\mathrm{S}$ treatment compared with the $\mathrm{SM}$ and $\mathrm{M}$ treatments. 
(Virden et al., 2004; Nocek et al., 2006; Zhang et al., 2008). However, only the source effect of $\mathrm{Cu}$ was considered in the current study. Cows in all treatments received $9.78 \mathrm{mg} / \mathrm{kg}$ of $\mathrm{Cu}$ from the basal diet and 12 $\mathrm{mg} / \mathrm{kg}$ of $\mathrm{Cu}$ from premixes, which in total exceeded the dietary $\mathrm{Cu}$ recommendations of NRC $(1989 ; 10 \mathrm{mg} /$ $\mathrm{kg}$ ) and $\mathrm{NRC}(2001 ; 16 \mathrm{mg} / \mathrm{kg})$ for lactating dairy cows with $650 \mathrm{~kg}$ of BW and producing $40 \mathrm{~kg}$ of milk/d. In this way, we avoided the possible system errors introduced by varying the $\mathrm{Cu}$ level in the diet.

\section{Lactation Performance}

Milk Production. The average milk yield of cows in the SM treatment tended to be consistently higher than yields in the other treatments. The higher milk production of cows in the SM treatment was observed from d 40 to 80 of the trial, which was immediately after a 2-d shortage of brewers grain at d 33 and 34 and during vaccination at $\mathrm{d} 62$. The authors inferred that supplementation of (HMTBA $)_{2}-\mathrm{Cu}$ during these challenges might have helped the cows cope with the stress and might explain the observed improvement in milk yield. In the literature, supplementation of organic forms of $\mathrm{Cu}$ to cattle under a variety of stresses resulted in improved $\mathrm{Cu}$ status (Nockels et al., 1993) and milk production (Olkowski et al., 1990).

Milk Components. Similar to other reports in the literature (Uchida et al., 2001; Ballantine et al., 2002), $\mathrm{Cu}$ supplementation did not affect milk fat or protein yield and content. Other studies have reported an increase in milk protein content when feeding organic $\mathrm{Cu}$ (Kincaid and Socha, 2004). It is interesting that in this trial, a trend was observed for changes in lactose content with treatments. The average lactose content in milk ranges from 4.5 to $4.8 \%$ and is rarely affected by treatments. In this trial, lactose levels were slightly lower than normal and might be associated with the wide range of changes in ambient temperature $(-32$ to $43^{\circ} \mathrm{C}$ ) during the trial.

\section{Nutrient Digestibility}

In this study, cows fed SM showed a trend toward higher NDF and ADF digestibility values. The effect of $\mathrm{Cu}$ on fiber digestibility has been widely studied, with some studies reporting improvements in fiber digestibility (Lopez-Guisa and Satter, 1992; Zhang et al., 2008) and others concluding the opposite (Martinez and Church, 1970; Ward et al., 1993). Fiber-degrading microorganisms are sensitive to rumen $\mathrm{pH}$. Ji et al. (2001) reported that at $\mathrm{pH}$ lower than 6.2 , the cellulolytic activity of bacteria is reduced. It is interesting that $\mathrm{Cu}$ sulfate supplementation has been shown to reduce rumen pH (Saxena and Srivastava, 1980) and to be deleterious to rumen microorganisms (Ward et al., 1993). However, when $\mathrm{Cu}$ was bound to an AA (Heinrichs and Conrad, 1983), it was not found to be toxic to rumen microorganisms. In light of these observations, a reduction of rumen $\mathrm{pH}$ and a deleterious effect on rumen microorganisms might be avoided by replacing inorganic $\mathrm{Cu}$ with an organic $\mathrm{Cu}$ source and might partially explain the improvements in fiber digestibility in cows fed SM. However, the reason the same effect was not observed in cows fed M is not clear. It is possible that rumen microorganisms need some $\mathrm{Cu}$ in the ionic (salt) form for optimal growth (Hubbert et al., 1958). A lack or excess of ionic $\mathrm{Cu}$, as in groups $\mathrm{M}$ and S, respectively, might hinder microbial metabolism and fiber digestion (Ward et al., 1993).

\section{Blood Analysis: Serum Cu and K}

In the serum, $\mathrm{Cu}$ exists in 3 major forms: ceruloplasmin, albumin-bound, or AA-bound forms. They are in 2 pools, between which $\mathrm{Cu}$ does not appear to be exchangeable: ceruloplasmin is the main pool corresponding to $\mathrm{Cu}$ exported from the liver to tissues, whereas the albumin- and AA-bound forms work as the second pool mainly corresponding to $\mathrm{Cu}$ transported from the intestine to the liver in the portal circulation (Cousins, 1985). Serum Cu, commonly used for diagnosis of $\mathrm{Cu}$ deficiency, is a poor indicator of $\mathrm{Cu}$ status and storage in the liver (Vermunt and West, 1994). In fact, dairy cows that are considered deficient, based on the evaluation of serum $\mathrm{Cu}$ concentration, have been found to be at or near a toxic state after examination of the liver $\mathrm{Cu}$ concentration (Blakley and Hamilton, 1985). Different from previous experiments, serum $\mathrm{Cu}$ was evaluated at $0,1,2$, and $4 \mathrm{~h}$ after the first feeding, with no significant diurnal changes. However, cows fed $\mathrm{SM}$ showed the highest average serum $\mathrm{Cu}$ followed by cows fed M, and cows fed S showed the lowest average serum $\mathrm{Cu}$. Unlike in previous experiments, we sampled not only at fasting but also at 1,2 , and $4 \mathrm{~h}$ after the first feeding, and serum $\mathrm{Cu}$ concentration of the same individual in a short continuous time was detected. Absorption of $\mathrm{Cu}$ mainly occurs in the rumen and small intestine of dairy cows, and absorbed $\mathrm{Cu}$ is transported through the blood. The primary route of $\mathrm{Cu}$ excretion is in the feces (approximately $280 \mathrm{mg} / \mathrm{d}$ ), and less than 1 and $0.5 \%$ of total $\mathrm{Cu}$ is excreted in the urine and milk, respectively. Because of the presence of $\mathrm{Cu}$ in endogenous excretion and hair loss, it becomes very difficult to measure $\mathrm{Cu}$ absorption. However, the average serum $\mathrm{Cu}$ across all time points could provide an indication of relative absorption when compared across treatments. The SM group showed the highest serum $\mathrm{Cu}$, which 
might suggest the highest absorption rate. The benefits of combining the 2 sources might be related to their sites of absorption. The $\mathrm{Cu}$ from sulfates might be absorbed across the rumen wall, whereas the $\mathrm{Cu}$ from HMTBA-Cu (rumen bypass) might be absorbed at the small intestine.

\section{CONCLUSIONS}

The results from this study indicated that replacing one-half of sulfate $\mathrm{Cu}$ with HMTBA-Cu increased plasma $\mathrm{Cu}$ concentration and tended to improve NDF and ADF apparent digestibility values and lactation performance of dairy cattle.

\section{ACKNOWLEDGMENTS}

This research was supported by the Novus International Inc. (St. Charles, MO). The authors thank the Hutubi Dairy Farm for providing the test site and animals.

\section{REFERENCES}

Allen, J. D., and J. W. Gawthorne. 1987. Involvement of the solid phase of rumen digesta in the interaction between copper, molybdenum and sulphur in sheep. Br. J. Nutr. 58:265-276.

AOAC. 1990. Official Methods of Analysis. 15th ed. Assoc. Off. Anal. Chem., Arlington, VA.

Arthington, J. D., L. R. Corall, and F. Blecha. 1996. The effect of molybdenum-induced copper deficiency on acute-phase protein concentrations, superoxide dismutase activity, leukocyte numbers, and lymphocyte proliferation in beef heifers. J. Anim. Sci. 74:211-217.

Ballantine, H. T., M. T. Socha, D. J. Tomlinson, A. B. Johnson, A. S. Fielding, J. K. Shearer, and S. R. Van Amstel. 2002. Effect of feeding complexed zinc, manganese, copper and cobalt to late gestation and lactating dairy cows on claw integrity, reproduction and lactation performance. Prof. Anim. Sci. 18:211-218.

Benke, M. B., S. P. Indraratne, X. Hao, C. Chang, and T. B. Goh. 2008. Trace element changes in soil after long-term cattle manure applications. J. Environ. Qual. 37:798-807.

Blakley, B. R., and D. L. Hamilton. 1985. Ceruloplasmin as an indicator of copper status in cattle and sheep. Can. J. Comp. Med. 49:405-408.

Bremner, I., W. R. Humphries, M. Phillippo, M. J. Walker, and P. C. Morrice. 1987. Iron-induced copper deficiency in calves: Doseresponse relationships and interactions with molybdenum and sulphur. Anim. Prod. 45:403-414.

Chapman, H. L. Jr., and M. C. Bell. 1963. Relative absorption and excretion by beef cattle of copper from various sources. J. Anim. Sci. 22:82-85.

Cousins, R. J. 1985. Absorption, transport and hepatic metabolism of copper and zinc: Special reference to metallothionein and ceruloplasmin. Physiol. Rev. 65:238-309.

Dick, A. T. 1953. The control of copper storage in the liver of sheep by inorganic sulphate and molybdenum. Aust. Vet. J. 29:233-239.

Ekinci, C., and G. A. Broderick. 1997. Effect of processing high moisture ear corn on ruminal fermentation and milk yield. J. Dairy Sci. 80:3298-3307.

Engle, T. E., and J. W. Spears. 2000. Effects of dietary copper concentration and source on performance and copper status of growing and finishing steers. J. Anim. Sci. 78:2446-2451.
FASS. 2010. Guide for Care and Use of Agricultural Animals in Research and Teaching. 3rd ed. Fed. Anim. Sci. Soc., Champaign, IL.

Gengelbach, G. P., and J. W. Spears. 1998. Effects of dietary copper and molybdenum on copper status, cytokine production, and humoral immune response of calves. J. Dairy Sci. 81:3286-3292.

Georgjevskii, V. I., and V. T. Samokin. 1982. Mineral Nutrition of Animals. Butterworths, London, UK.

Gooneratne, S. R., W. T. Buckley, and D. A. Christensen. 1989. Review of copper deficiency and metabolism in ruminants. Can. J. Anim. Sci. 69:819-845.

Heinrichs, A. J., and H. R. Conrad. 1983. Rumen solubility and breakdown of metal proteinate compounds. J. Dairy Sci. 66(Suppl. 1):147. (Abstr.)

Huang, W. M., S. L. Li, Z. J. Cao, and Z. S. Wang. 2009. A methodological study on the determination of milk urea nitrogen. Chinese J. Anim. Sci. 49:54-56.

Hubbert, F., Jr., E. Cheng, and W. Burroughs. 1958. Mineral requirement of rumen microorganisms for cellulose digestion in vitro. J. Anim. Sci. 178:559-568.

Ivan, M. 1988. Effect of faunation on ruminal solubility and liver content of copper in sheep fed low or high copper diets. J. Anim. Sci. $66: 1496-1501$.

Ivan, M. 1989. Effects of faunation and type of dietary protein on gastric solubility and liver content of copper in sheep. J. Anim. Sci. 67:3028-3035.

Ji, Y. L. 2001. Practical Cattle Science. Chinese Agriculture Press, Beijing, China.

Kegley, E. B., and J. W. Spears. 1994. Bioavailability of feed-grade copper sources (oxide, sulfate, or lysine) in growing cattle. J. Anim. Sci. 72:2728-2734.

Kincaid, R. L., R. M. Blauwiekel, and J. D. Cronrath. 1986. Supplementation of copper as copper sulfate or copper proteinate for growing calves fed forages containing molybdenum. J. Dairy Sci. 69:160-163.

Kincaid, R. L., and M. T. Socha. 2004. Inorganic versus complexed trace mineral supplements on performance of dairy cows. Prof. Anim. Sci. 20:66-73.

Loeffler, S. H., M. T. Socha, D. J. Tomlinson, and A. B. Johnson. 2007. Effects of supplementing complexed zinc, manganese, copper and cobalt on lactation and reproductive performance of intensively grazed lactating dairy cattle on the South Island of New Zealand. Anim. Feed Sci. Technol. 137:69-83.

Lopez-Guisa, J. M., and L. D. Satter. 1992. Effect of copper and cobalt addition on digestion and growth in heifers diets contenting alfalfa or corn crop residues. J. Dairy Sci. 75:247-256.

Martinez, A., and D. C. Church. 1970. Effect of various mineral elements on in vitro rumen cellulose digestion. J. Anim. Sci. 31:982990.

McDowell, L. R. 1992. Minerals in Animal and Human Nutrition. Academic Press, New York, NY.

Nocek, J. E., M. T. Socha, and D. J. Tomlinson. 2006. The effect of trace mineral fortification level and source on performance of dairy cattle. J. Dairy Sci. 89:2679-2693.

Nockels, C. F., J. D. Bonis, and J. Torrent. 1993. Stress induction affects copper and zinc balance in calves fed organic and inorganic copper and zinc sources. J. Anim. Sci. 71:2539-2545.

NRC. 1989. Nutrient Requirements of Dairy Cattle. 6th ed. Natl. Acad. Sci., Washington, DC.

NRC. 2001. Nutrient Requirements of Dairy Cattle. 7th ed. Natl. Acad. Sci., Washington, DC.

Olkowski, A. A., S. R. Gooneratne, and D. A. Christensen. 1990. Effects of diets of high sulphur content and varied concentrations of copper, molybdenum and thiamine on in vitro phagocytic and candidacidal activity of neutrophils in sheep. Res. Vet. Sci. 48:82-86.

SAS Institute. 2004. The SAS User's Guide: Statistics. SAS Institute Inc., Cary, NC.

Saxena, K. K., and R. V. Srivastava. 1980. Effect of cobalt and copper supplementation on the ruminal volatile fatty acid concentration and microbial population in Hariana calves. Indian J. Anim. Sci. $56: 457-471$. 
Sharman, E. D., J. J. Wagner, C. K. Lanrson, J. S. Schutz, N. E. Davis, and T. E. Engle. 2008. The effects of trace mineral source on performance and health of newly received steers and the impact of cobalt concentration on performance and lipid metabolism during the finishing phase. Prof. Anim. Sci. 24:430-438.

Siciliano-Jones, J. L., M. T. Socha, D. J. Tomllnson, and J. M. DeFrain. 2008. Effect of trace mineral source on lactation performances, claw integrity, and fertility of dairy cattle. J. Dairy Sci. 91:1985-1995.

Spears, J. W. 2003. Trace mineral bioavailability in ruminants. J. Nutr. 133:1506-1509.

Stabel, J. R., and J. W. Spears. 1993. Effects of copper deficiency on tissue, blood characteristics, and immune function of calves challenged with infectious bovine rhinotracheitis virus and Pasteurella hemolytica. J. Nutr. 71:1247-1255.

Suttle, N. F. 1991. The interactions between copper, molybdenum, and sulphur in ruminant nutrition. Annu. Rev. Nutr. 11:121-140.

Uchida, K. C., P. Mandebvu, C. S. Ballard, C. J. Sniffen, and M. P. Carter. 2001. Effect of feeding a combination of zinc, manganese and copper amino complexes, and cobalt glucoheptonate on performance of early lactation high production dairy cows. Anim. Feed Sci. Technol. 93:193-203.

Van Soest, P. J., J. B. Robertson, and B. A. Lewis. 1991. Methods for dietary fiber, neutral detergent fiber, and nonstarch polysaccharides in relation to animal nutrition. J. Dairy Sci. 74:3583-3597.
Vermunt, J. J., and D. M. West. 1994. Predicting copper status in beef cattle using serum copper concentrations. N. Z. Vet. J. 42:194195.

Virden, W. S., J. B. Yeatman, S. J. Barber, K. O. Willeford, T. L. Ward, T. M. Fakler, R. F. Wideman Jr., and M. T. Kidd. 2004. Immune system and cardiac functions of progeny chicks from dams fed diets differing in zinc and manganese level and source. Poult. Sci. $83: 344-351$.

Ward, J. D., J. W. Spears, and E. B. Kegley. 1993. Effect of copper level and source (copper lysine vs. copper sulfate) on copper status, performance, and immune response in growing steers fed diets with or without supplemental molybdenum and sulfur. J. Anim. Sci. 71:2748-2755.

Ward, J. D., J. W. Spears, and E. B. Kegley. 1996. Bioavailability of copper proteinate and copper carbonate relative to copper sulfate in cattle. J. Dairy Sci. 79:127-132.

Wittenberg, K. M., R. J. Boila, and M. A. Shariff. 1990. Comparison of copper sulfate and copper proteinate as copper sources for copper-depleted steers fed high molybdenum diets. Can. J. Anim. Sci. 70:895-904

Zhang, W., R. L. Wang, D. O. Kleemann, D. X. Lu, X. P. Zhu, C. X. Zhang, and Z. H. Jia. 2008. Effects of dietary copper on nutrient digestibility, growth performance and plasma copper status in cashmere goats. Small Rumin. Res. 74:188-193. 